UDC 616-018.1 $712.4: 57.088$

\title{
Monitoring of transplanted human Mesenchymal Stem Cells from Wharton's Jelly in xenogeneic systems in vivo
}

\author{
M. V. Kovalchuk ${ }^{1,2}$, N. S. Shuvalova ${ }^{2}$, I. O. Pokholenko ${ }^{1,2}$, \\ M. V. Dragulyan ${ }^{1}$, T. P. Gulko ${ }^{1}$, O. G. Deryabina ${ }^{2}$, V. A. Kordium ${ }^{1}$ \\ ${ }^{1}$ Institute of Molecular Biology and Genetics, NAS of Ukraine \\ 150, Akademika Zabolotnoho Str., Kyiv, Ukraine, 03680 \\ 2 State Institute of Genetic and Regenerative Medicine, NAMS of Ukraine \\ 67, Vyshhorodska Str., Kyiv, Ukraine, 04114 \\ kovmv@ukr.net
}

\begin{abstract}
Mesenchymal stem cells (MSCs) are ideal candidates for cell-based therapy aimed at tissue repair and immunomodulation. Aim. To study the survival of transplanted human MSCs from umbilical cord Wharton's Jelly (hWJ-MSCs) in the animal model of experimental osteoarthritis (OA) in rats after injecting cells into a knee joint and to explore the effect of collagen scaffold on the cell survival in vivo. Methods. MSC isolation and cultivation in vitro. Immunological phenotyping of propagated hWJ-MSCs was performed by flow cytometry. The retention of transplanted cells was studied by the PCR revealing of human specific sequences in genomic DNA extracted from animal tissues. Results. hWJ-MSCs, both individual and grown on scaffold, were used and it was shown by PCR that human alpha-satellite DNA was detected on the first day in the immunocompetent OA animals inside the injured knee joint. In the collagen matrix (in the model of subcutaneous implantation) human alpha-satellite DNA was detected on the $5^{\text {th }}$ day but was not detected on the $12^{\text {th }}$ day. Conclusions. According to the PCR results, hWJ-MSCs survived in the OA animal model for a short period. Collagenic scaffold increased the residence time of donor cells in the recipients. hWJ-MSCs may be considered as a perspective cell source for the treatment of OA in human.
\end{abstract}

Ke y w o r d s: hWJ-MSCs, alpha-satellite DNA, 3-D scaffolds, cell retention, PCR.

\section{Introduction}

MSCs have been widely investigated over the years due to a combination of unique features such as their availability, ease of cultivation, multiplication ex vi$v o$, and positive therapeutic effects in animal models of various human diseases. A wide application of cell therapy with MSCs in practice depends on complete understanding of mechanisms of their action. MSCs first attracted attention due to their ability to differentiate into different directions $[1,2]$. At present, more and more researchers suggest that the regenerative potential of MSCs is associated with pa- racrine actions that coordinate the complex processes of restoration of damaged tissues and organs [3-7]. MSCs have been shown to secrete numerous growth factors like the transforming growth factor $\beta$, granulocyte-macrophage colony-stimulating factor, hepatocyte growth factor, vascular endothelial growth factor, cytokines (interleukin 6, 10) and chemokines, prostaglandins, etc. [8-10].

In vitro MSC characteristics usually suggest their in vivo potency. However, the in vitro predictions do not always correlate with the in vivo results. Successful application of MSC-therapy to humans requires the characterization through in vivo animal models,

(C) 2015 M. V. Kovalchuk et al.; Published by the Institute of Molecular Biology and Genetics, NAS of Ukraine on behalf of Biopolymers and Cell. This is an Open Access article distributed under the terms of the Creative Commons Attribution License (http://creativecommons.org/licenses/by/4.0/), which permits unrestricted reuse, distribution, and reproduction in any medium, provided the original work is properly cited 
and xenogeneic transplantation is needed for the pilot study of therapeutic features of human MSCs. Although MSCs are immunosuppressive and immunoprivileged and can be tolerated after allotransplantation $[11,12]$, the cells cannot overcome the immunological barrier in a xenogeneic environment [13]. However, the MSC therapeutic efficiency was confirmed in several different cross-species models [14]. Numerous studies have demonstrated that the transplanted xenogeneic MSCs are able to avoid the immune surveillance initially (e.g., during one week after transplantation), but are finally rejected even with immunosuppression [15]. Despite some limitations of xenogeneic animal models in the study of human MSCs, the animal model assays improve our understanding of the mechanisms underlying the therapeutic effects.

MSCs have a significant potential for the treatment of OA, that is why several MSC-therapies are intensively developed for the OA-associated cartilage defects treatment $[16,17]$. However, many questions remain unanswered such as the required cellular dose, the best source of MSCs, the fate of transplanted cells, etc.] [17]. hWJ-MSCs are considered to be much more proliferative, immunosuppressive, and even therapeutically active than other MSCs, and thus, more prospective for the OA treatment [18]. The MSCs survival after their transplantation is crucial to the therapeutic efficacy but there is little information about the fate of transplanted cells. In this context, the aim of the present short-term study was to examine the survival of hWJ-MSCs in immunocompetent OA rats in an early period following the transplantation suggesting that at this stage the immune system contribution to the elimination of cells would not be essential. The survival of collagen scaffold immobilized hWJ-MSCs was also assessed in vivo.

\section{Materials and Methods}

\section{Experimental Design}

For the overall experimental design, one source of cells has been assayed in vivo in two site-directed implantation models for examining their retention. hWJ-MSCs were used after the second passage in culture. For Experiment 1 (local injection), culture expanded hWJ-MSCs were injected into a knee joint. For Experiment 2, the cells were seeded in 3-D scaffolds and implanted subcutaneously. All the experiments were performed without immunosuppression. To track the fate of the donor hMSCs, the tissue samples were collected at different time points for PCR analysis.

\section{Laboratory animals}

Wistar rats (males with weight 180-200 g) and mouse line BALB/c were used as experimental animals. The animals were kept under standard conditions. All manipulations with animals were carried out in accordance with the requirements of Guide for the Care and Use of laboratory Animals [19] and the law of Ukraine N 3447-IV of 21.02.2006 «The protection of animals from cruel behavior» [20].

\section{Isolation and culture of hWJ-MSCs}

The human umbilical cord samples were collected after informed consent of puerpera and processed by the method described earlier [21]. To confirm a proper surface markers' expression (CD73, CD90, CD105 and CD34), the ex vivo propagated cells were analysed by flow cytometry at passage 2 [22]. FACSanalysis of the MSC markers expression (MAbs CD105, CD90, CD73-BD, USA) was performed with BD FACSAria cell sorter (Becton Dickinson Biosciences, San Jose, CA, USA) and BD FACSDiva software (v 6.1.2).

\section{Obtaining the experimental model of osteoarthritis with I-acetic acid in rats}

The animal models were established by means of intra-articular injection of iodine-acetic acid. Rats were injected with $0.1 \mathrm{ml}$ of iodine-acetic acid ( $3 \mathrm{mg}$ of iodine-acetic acid in $50 \mu \mathrm{l}$ of $0.9 \% \mathrm{NaCl}$ ) and monitored for signs of arthritis onset based on paw swelling and clinical scores [23]. Animals with osteoarthritic signs (score 2, pronounced edema) were enrolled in the study $(\mathrm{n}=19)$. On day 7 , osteoarthritic and intact $(\mathrm{n}=10)$ animals were injected with $1.5 \times 10^{6}$ cells in $100 \mu 1$ of PBS. Additionally, two animals (sham-operated males) received injections of an equivalent volume of PBS. 
Fabrication of collagen scaffolds

and cell seeding.

Type I collagen was extracted from bovine tendons using the pepsin-based acidic extraction method described in [24], lyophilized, and stored at $-20{ }^{\circ} \mathrm{C}$ for further application. Porous collagen scaffolds were prepared by freeze-drying the collagen type I solution $(10 \mathrm{mg} /$ $\mathrm{ml})$ in $0.1 \mathrm{M}$ acetic acid as described earlier [25]. The scaffolds were UV-treated, swollen overnight in $0.1 \mathrm{M}$ HEPES $\mathrm{pH} 7.4$, and then equilibrated in cell cultivation medium for 24 hours at $37{ }^{\circ} \mathrm{C}$ and $5 \% \mathrm{CO}_{2}$. Approximately $1 \times 10^{6}-1.5 \times 10^{6} \mathrm{hWJ}-\mathrm{MSCs}$ were seeded per $1 \mathrm{~cm}^{2}$ of scaffold. The cells were cultivated on scaffold for 24 hours at $37{ }^{\circ} \mathrm{C}$ and $5 \% \mathrm{CO}_{2}$ prior to implantation. After implantation for different time points, the scaffolds were removed.

\section{Isolation of DNA}

Genomic DNA was extracted from synovial fluid using the salt out method (according to Grinberg,1989) [26]. DNA from synovial tissues (swabs) and scaffolds was isolated as previously described by the method of Bruijn et al. [27]. The DNA concentration and purity were determined by optical density using the Thermo Scientific NanoDrop 2000 UV-Vis spectrophotometer.

\section{Polymerase chain reaction}

To detect transplanted human cells in rats and mice, the polymerase chain reaction analysis was performed using primers to amplify human-specific 850 bp fragment of the alpha-satellite DNA on human chromosome 17 [28]; polymerase chain reaction was performed as described in the work of Becker et al. [28]. Each reaction contained the same amount of genomic DNA template (100 ng in $20 \mu \mathrm{l}$ of reaction mixture). DNA from cultured hWJ-MSCs served as a positive control and DNA from an untreated animal was used as a negative control.

Oligonucleotides used for PCR as described by Warburton et al. [29]:

Cr17_1a f (5'-GGG ATA ATT TCA GCT GAC TAA ACA G-3 ') 15..39

Cr17_2b r (5'TTC CGT TTA GTT AGG TGC AGT TAT C-3 ‘) $867 . .891$
Separation of amplification products was performed in $1.2 \%$ agarose gel in TAE with subsequent visualization under ultraviolet light after ethidium bromide staining. GeneRuler 100 bp DNA Ladder («Fermentas», Lithuania) was used as a marker of PCR product fragment length.

\section{Results and Discussion}

hWJ-MSCs were isolated from Wharton's Jelly, propagated in culture, harvested at the second passage and confirmed to be MSCs according to the International Society for Cellular Therapy's minimal criteria for defining MSCs. In accordance with the FACS analysis hWJ-MSCs were positive for CD73, CD90, and CD105 antigens more than $90 \%$ and were negative for CD34 antigen $(<2 \%)$. The cell viability was confirmed with trypan blue dye exclusion $(>95 \%)$. The retention of hWJ-MSCs in the animal models was detected through the presence of the human-specific alpha-satellite DNA in the analysed samples. A sensitive PCR assay was performed for detection of the human cells in animal tissues. The method has a high sensitivity due to the highly repetitive alpha-satellite sequence. PCR primers we-

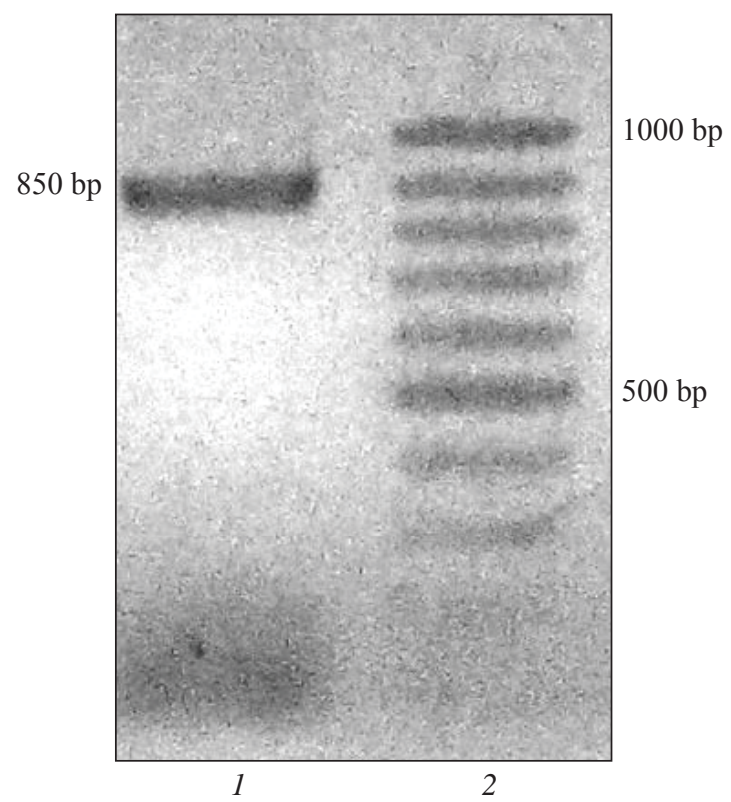

Fig. 1. Electrophoregram of amplification product with primers to the human alpha-satellite DNA in $1.2 \%$ agarose gel. $1-\mathrm{hWJ}$ MSCs DNA; 2 - marker 100 bp DNA Ladder (Fermentas) 


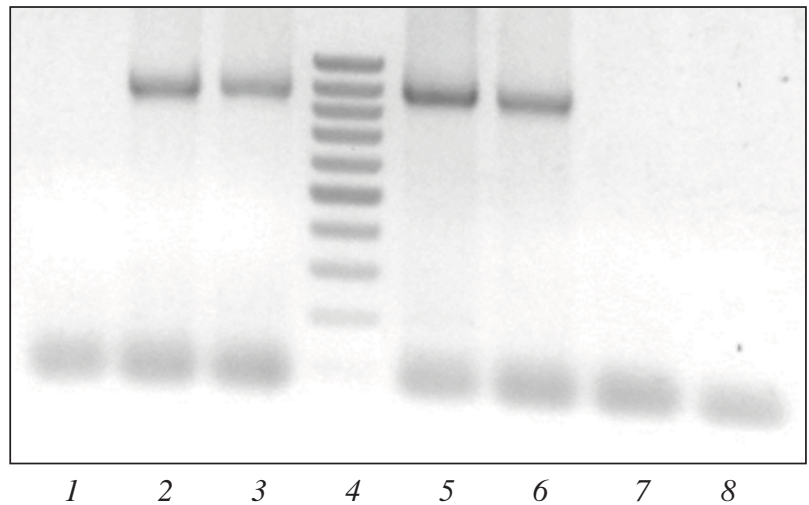

Fig. 2. The results of PCR for the presence of human alphasatellite DNA samples from affected joints cavities of rats after administration of hWJ-MSCs at different time points. 1 - flush joint after administration of PBS (control) $30 \mathrm{~min} ; 2$ - synovial washout, $30 \mathrm{~min}$; 3 - synovial tissue, $30 \mathrm{~min}$; 4 - molecular weight marker, 100 bp DNA Ladder (Fermentas); 5 - hWJ-MSCs; 6 - synovial washout, $24 \mathrm{~h} ; 7$ - synovial washout, 7 days; 8 synovial washout after administration of PBS (control), 7 days

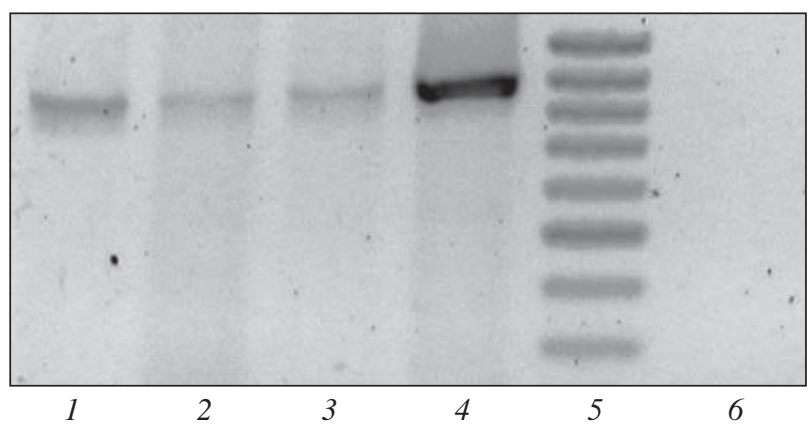

Fig. 3. Results of PCR for the presence of human alpha-satellite DNA samples from 3-D collagen matrices populated with hWJMSCs after subcutaneous implantation into the BALB/c mice. 1 3-D hWJ-MSCs -seeded matrix prior to implantation; 2 - 24 hours after implantation; $3-5$ days after implantation; $4-\mathrm{hWJ}$ MSCs (positive control); 5 - molecular weight marker, $100 \mathrm{bp}$ DNA Ladder (Fermentas); 6 - 12 days after implantation

Table 1. hWJ-MSC detection by alpha-satellite DNA PCR

\begin{tabular}{|l|c|c|c|c|}
\hline \multirow{2}{*}{$\begin{array}{c}\text { Post } \\
\text { transplantation } \\
\text { time }\end{array}$} & \multicolumn{2}{|c|}{$\begin{array}{c}\text { PCR-positive rats } \\
\text { with osteoarthritis }\end{array}$} & \multicolumn{2}{c|}{$\begin{array}{c}\text { PCR-positive } \\
\text { intact rats }\end{array}$} \\
\cline { 2 - 5 } & $\begin{array}{c}\text { Sinovial } \\
\text { washout }\end{array}$ & Sinovium & $\begin{array}{c}\text { Sinovial } \\
\text { washout }\end{array}$ & Sinovium \\
\hline $30 \min (\mathrm{n}=2)$ & 2 & 2 & 2 & 2 \\
$2 \mathrm{hr}(\mathrm{n}=2)$ & 2 & 2 & 2 & 2 \\
$24 \mathrm{~h} \quad(\mathrm{n}=2)$ & 2 & 2 & 2 & 2 \\
7 days $(\mathrm{n}=2)$ & 0 & 0 & 0 & 0 \\
\hline
\end{tabular}

re specific for the hMSC donor DNA with the sensitivity of $1 / 10^{5}-1 / 10^{6}$, in serial dilutions. The electrophoregram of alpha-human DNA PCR product is shown in Fig. 1.

To study the survival of hWJ-MSCs in OA animal, the experimental rats were injected with cells through intra-articular route. The animals were sacrificed according to the standard protocols for euthanasia after $0.5,2,24$ hours and 7 days of transplantation. The number of animals selected for PCR analysis was minimized to two at each harvest time point (Table 1). The joints were opened, the synovial washouts and tissues of hWJ-MSCs injected (injured and healthy) and control joints were used to isolate DNA, which was used as a template for PCR (Fig. 2).

As seen from the results of PCR, the human DNA was detected in joint cavity, at least during the first day. At the $7^{\text {th }}$ day of transplantation, the alpha-satellite DNA in amplification reaction was not detected. Early cell loss was observed in both OA-induced and intact animal groups. The exact date of human DNA clearance remains unclear because the samples were harvested on days 1 and 7 after in vivo hWJ-MSCs delivery.

It is known that biocompatible 3-D scaffolds can prolong the the transplanted cells survival in the injury site. In order to examine whether the collagen scaffolds improve the hWJ-MSCs survival in the xenogeneic setting, the same hWJ-MSCs were seeded to scaffolds and subcutaneously implanted into immunocompetent mice without appropriate immune suppression. The collagen matrices were recovered from the implantation sites with different time points at 1, 5 and 12 days for the isolation of genomic DNA. The results of PCR for the presence of human DNA in the grafts in mice are shown in Fig. 3.

The PCR assay demonstrated the complete loss of human DNA in the samples at the $12^{\text {th }}$ day. This suggests that $\mathrm{hWJ}-\mathrm{MSC}$ s survived in the BALB/c mice at least for the first week of post-transplantation.

Using a species-specific PCR analysis of the human genomic DNA we have revealed short-time survival of the transplanted cells in two different animal models in vivo. It is known that a local administration of cells promotes a direct physical contact of 
donor and recipient cells which leads to a more efficient exchange of the molecular signals that coordinate regenerative processes. We have observed a sudden cell loss during the first days following the local hWJ-MSCs transplantation in the applied experimental model of OA. The early cell loss during intra-articular injection can occur for a variety of reasons. For example, the influx of monocytes/ macrophages into the injured knee joint provides unfavourable conditions for the exogenous stem cell survival, confirmed by the absence of human DNA in the samples. On the other hand, hypoxia and serum deprivation within the first 24 hours after transplantation contribute to the cell death. Additionally, a sharp decrease in detectability of the human DNA in animal tissues may be associated with the PCR limitation. All mentioned above reasons can be relevant. In contrast, the hWJ-MSCs immobilised in a scaffold avoided an immediate contact with the host immune cells in the early post-transplantation period as they were partially protected and thus did not undergo a direct immune attack by the host within the first week after transplantation. Moreover, a scaffold partially mimics in vivo conditions that prolongs the cell survival. There was an appreciable difference in the survival time of the hWJ-MSCs immobilized on a scaffold and transplanted as a three-dimensional structure compared to those transplanted as the cell suspension. A tendency to early death of the transplanted human MSCs in immunocompetent animals is shown in recent studies $[30,31]$. Toupet et al. reported that survival and biodistribution of xenogeneic MSCs are not affected by the degree of inflammation in arthritis [31]. On the other hand several studies indicated that even such short-term viability of transplanted cells (one day) can be sufficient to initiate the regeneration of damaged tissues $[15,32$, 33]. Therefore the therapeutic potential and functional activity of human MSCs may initially be tested in such animal models. Our data suggest that the optimization of experimental protocols for the $\mathrm{hWJ}$-MSCs isolation, cell preconditioning and cell formulation are required to improve the cell survival after transplantation.

\section{Conclusions}

$\mathrm{hWJ}$-MSCs were applied in the OA animal model to assess a potential of these cells for treatment of OA. According to the PCR results, hWJ-MSCs survived in the OA animals for a short period. The collagen scaffold increased the cell residence time in recipients. hWJ-MSCs may be considered as a perspective cell source for the treatment of OA in humans.

\section{REFERENCES}

1. Pittenger MF, Mackay AM, Beck SC, Jaiswal RK, Douglas R, Mosca JD, Moorman MA, Simonetti DW, Craig S, Marshak $D R$. Multilineage potential of adult human mesenchymal stem cells. Science. 1999;284(5411):143-7.

2. Sasaki M, Abe R, Fujita Y, Ando S, Inokuma D, Shimizu $H$. Mesenchymal stem cells are recruited into wounded skin and contribute to wound repair by transdifferentiation into multiple skin cell type. J Immunol. 2008;180(4):2581-7.

3. Ankrum J, Karp JM. Mesenchymal stem cell therapy: Two steps forward, one step back. Trends Mol Med. 2010;16(5): 203-9.

4. Abarbanell AM, Coffey AC, Fehrenbacher JW, Beckman DJ, Herrmann JL, Weil B, Meldrum DR. Proinflammatory cytokine effects on mesenchymal stem cell therapy for the ischemic heart. Ann Thorac Surg. 2009;88(3):1036-43.

5. Wu L, Leijten JC, Georgi N, Post JN, van Blitterswijk CA, Karperien $M$. Trophic effects of mesenchymal stem cells increase chondrocyte proliferation and matrix formation. Tissue Eng Part A. 2011;17(9-10):1425-36.

6. ter Huurne M, Schelbergen R, Blattes R, Blom A, de Munter W, Grevers LC, Jeanson J, Noël D, Casteilla L, Jorgensen C, van den Berg W, van Lent PL. Antiinflammatory and chondroprotective effects of intraarticular injection of adiposederived stem cells in experimental osteoarthritis. Arthritis Rheum. 2012;64(11):3604-13.

7. Maumus M, Jorgensen C, Noël D. Mesenchymal stem cells in regenerative medicine applied to rheumatic diseases: role of secretome and exosomes. Biochimie. 2013;95(12):2229-34.

8. Tamama K, Kerpedjieva SS. Acceleration of wound healing by multiple growth factors and cytokines secreted from multipotential stromal cells/mesenchymal stem cells. Adv Wound Care (New Rochelle). 2012;1(4):177-182.

9. Song YS, Lee HJ, Doo SH, Lee SJ, Lim I, Chang KT, Kim SU. Mesenchymal stem cells overexpressing hepatocyte growth factor (HGF) inhibit collagen deposit and improve bladder function in rat model of bladder outlet obstruction. Cell Transplant. 2012;21(8):1641-50.

10. Liu S, Hou KD, Yuan M, Peng J, Zhang L, Sui X, Zhao B, Xu W, Wang A, Lu S, Guo Q. Characteristics of mesenchymal stem cells derived from Wharton's jelly of human umbilical cord and for fabrication of non-scaffold tissue-engineered cartilage. J Biosci Bioeng. 2014;117(2):229-35. 
M. V. Kovalchuk, N. S. Shuvalova, I. O. Pokholenko et al.

11. González MA, Gonzalez-Rey E, Rico L, Büscher D, Delgado M. Treatment of experimental arthritis by inducing immune tolerance with human adipose-derived mesenchymal stem cells. Arthritis Rheum. 2009;60(4):1006-19.

12. Pigott JH, Ishihara A, Wellman ML, Russell DS, Bertone AL. Investigation of the immune response to autologous, allogeneic, and xenogeneic mesenchymal stem cells after intra-articular injection in horses. Vet Immunol Immunopathol. 2013; 156(1-2):99-106.

13. Li J, Ezzelarab MB, Cooper DK. Do mesenchymal stem cells function across species barriers? Relevance for xenotransplantation. Xenotransplantation. 2012;19(5):273-85.

14. Lin CS, Lin G, Lue TF. Allogeneic and xenogeneic transplantation of adipose-derived stem cells in immunocompetent recipients without immunosuppressants. Stem Cells Dev. 2012;21(15):2770-8.

15. Chuang CK, Lin KJ, Lin CY, Chang YH, Yen TC, Hwang SM, Sung $\mathrm{LY}$, Chen $\mathrm{HC}$, Hu YC. Xenotransplantation of human mesenchymal stem cells into immunocompetent rats for calvarial bone repair. Tissue Eng Part A. 2010;16(2):479-88.

16. Wakitani S, Imoto K, Yamamoto T, Saito M, Murata N, Yoneda $M$. Human autologous culture expanded bone marrow mesenchymal cell transplantation for repair of cartilage defects in osteoarthritic knees. Osteoarthritis Cartilage. 2002; 10(3):199-206.

17. Qi Y, Feng G, Yan W. Mesenchymal stem cell-based treatment for cartilage defects in osteoarthritis. Mol Biol Rep. 2012;39(5):5683-9.

18. Kim DW, Staples M, Shinozuka K, Pantcheva P, Kang SD, Borlongan CV. Wharton's jelly-derived mesenchymal stem cells: phenotypic characterization and optimizing their therapeutic potential for clinical applications. Int $J$ Mol Sci. 2013;14(6):11692-712.

19. Guide for the care and use of laboratory animals, Washington: National Academy Press, 1996. 136 p.

20. Law of Ukraine «The protection of animals from cruel behavior» from 21.02.2006 N 3447-IV. Vidomosti of Verkhovna Rada of Ukraine. 2006; 27:990.

21. Maslova OO, Shuvalova NS, Sukhorada OM, Zhukova SM, Deryabina OG, Makarenko MV, Govseiev DO, Kordium VA. Heterogeneity of umbilical cords as a source for mesenchymal stem cells. Dataset Papers in Biology. 2013;2013:1-4.

22. Dominici M, Le Blanc K, Mueller I, Slaper-Cortenbach I, Marini F, Krause D, Deans R, Keating A, Prockop Dj, Horwitz $E$. Minimal criteria for defining multipotent mesenchymal stromal cells. The International Society for Cellular Therapy position statement. Cytotherapy. 2006;8(4):315-7.
23. Bendele AM. Animal models of osteoarthritis. J Musculoskelet Neuronal Interact. 2001;1(4):363-76.

24. Zeugolis DI, Li B, Lareu RR, Chan CK, Raghunath M. Collagen solubility testing, a quality assurance step for reproducible electro-spun nano-fibre fabrication. A technical note. J Biomater Sci Polym Ed. 2008;19(10):1307-17.

25. Pokholenko IaO, Chetyrkina MD, Dubey LV, Dubey IYa, Moshynets OV, Sheludko EV, Shpylova SP, Degtiarova MI, Kordium VA. Development and characterization of porous functionalized collagen scaffolds for delivery of FGF-2. Biopolym Cell. 2014; 30(3):216-22.

26. Grimberg J, Nawoschik S, Belluscio L, McKee R, Turck A, Eisenberg A. A simple and efficient non-organic procedure for the isolation of genomic DNA from blood. Nucleic Acids Res. 1989;17(20):8390.

27. Biase FH, Franco MM, Goulart LR, Antunes RC. Protocol for extraction of genomic DNA from swine solid tissues. Genet Mol Biol. 2002;25(3):313-5.

28. Becker M, Nitsche A, Neumann C, Aumann J, Junghahn I, Fichtner I. Sensitive PCR method for the detection and realtime quantification of human cells in xenotransplantation systems. Br J Cancer. 2002;87(11):1328-35.

29. Warburton PE, Greig GM, Haaf T, Willard HF. PCR amplification of chromosome-specific alpha satellite DNA: definition of centromeric STS markers and polymorphic analysis. Genomics. 1991;11(2):324-33.

30. Agrawal H, Shang H, Sattah AP, Yang N, Peirce SM, Katz AJ. Human adipose-derived stromal/stem cells demonstrate short-lived persistence after implantation in both an immunocompetent and an immunocompromised murine model. Stem Cell Res Ther. 2014;5(6):142.

31. Toupet K, Maumus M, Luz-Crawford P, Lombardo E, LopezBelmonte J, van Lent P, Garin MI, van den Berg W, Dalemans W, Jorgensen C, Noël D. Survival and biodistribution of xenogenic adipose mesenchymal stem cells is not affected by the degree of inflammation in arthritis. PLoS One. 2015; 10(1):e0114962.

32. Roh JD, Sawh-Martinez R, Brennan MP, Jay SM, Devine L, Rao DA, Yi T, Mirensky TL, Nalbandian A, Udelsman B, Hibino N, Shinoka T, Saltzman WM, Snyder E, Kyriakides TR, Pober JS, Breuer CK. Tissue-engineered vascular grafts transform into mature blood vessels via an inflammationmediated process of vascular remodeling. Proc Natl Acad Sci U S A. 2010;107(10):4669-74.

33. Lee RH, Pulin AA, Seo MJ, Kota DJ, Ylostalo J, Larson BL, Semprun-Prieto L, Delafontaine P, Prockop DJ. Intravenous hMSCs improve myocardial infarction in mice because cells embolized in lung are activated to secrete the anti-inflammatory protein TSG-6. Cell Stem Cell. 2009;5(1):54-63. 


\section{Моніторинг трансплантованих мезенхімальних стовбурових клітин Вартонового студня пуповини людини in vivo у ксеногених системах}

М. В. Ковальчук, Н. С. Шувалова,

Я. О. Похоленко, М. В. Драгулян, Т. П. Гулько, О. Г. Дерябіна, В. А. Кордюм

Мезенхімальні стовбурові клітини (МСК) є ідеальними кандидатами для відновлення тканин та імуномодуляції при клітинній терапії. Мета. Вивчити виживання трансплантованих МСК Вартанового студню пуповини людини (МСКВC) на моделі експериментального остеоартрозу у щурів (введення клітин в колінний суглоб) та дослідити вплив коллагенового матриксу на виживання МСК-ВC in vivo. Методи. Виділення і культивування МСК-ВС in vitro. Імунологічне фенотипування мультиплікованих МСК-ВС проведено за допомогою проточної цитофлуорометрії. Збереження трансплантованих клітин вивчали за допомогою ПЛР, що виявляє специфічні для людини послідовності в геномній ДНК, ізольованій з тканин тварин. Результи Використано індивідуальні та вирощені на матриксі МСК-ВС, ПЛР показано, що альфа-сателітна ДНК людини в пошкодженому суглобі у імунокомпетентних травмованих тварин виявлялась за добу. У колагеновому матриксі (в моделі підшкірної імплантації) ДНК людини була виявлена на 5, але не детектувалась на 12 добу. Висновки. За результатами ПЛР МСКВС виживали у тварин з остеоартрітом протягом нетривалого часу. Колагеновий матрикс збільшував тривалість перебування МСК-ВС у реципієнтів. МСК-ВС можуть розглядатися як перспективне джерело клітин для лікування остеоартриту у людини.

К л юч о в і с л о в а: МСК-BC, альфа-сателітна ДНК, 3-D матрикс, виживання клітин, ПЛР.
Мониторинг трансплантированных мезенхимальных стволовых клеток Вартонового студня пуповины человека in vivo в ксеногенных системах

М. В. Ковальчук, Н. С. Шувалова, Я. А. Похоленко, М. В. Драгулян, Т. П. Гулько, Е. Г. Дерябина, В. А. Кордюм

Мезенхимальные стволовые клетки (МСК) являются идеальными кандидатами для восстановление тканей и иммуномодуляции при клеточной терапии. Цель. Изучить выживание трансплантированных МСК Вартонового студня пуповины человека (МСК-BC) на модели экспериментального остеоартроза у крыс (введение клеток в коленный сустав), и исследовать влияние коллагенового матрикса на выживание МСК-BC in vivo. Методы. Выделение и культивирование МСК-ВС in vitro. Иммунологическое фенотипирование мультиплицированных МСК-ВС проведено с помощью проточной цитофлуорометрии. Сохранение трансплантированных клеток изучали с помощью ПЦР, выявляющей специфические для человека последовательности в геномной ДНК, изолированной из тканей животных. Результы. Исследование индивидуальних и выращенные на матриксе МСК-ВС, с помощью ПЦР, показало, что альфа-сателлитная ДНК человека детектировалась в первые сутки у иммунокомпетентных животных в поврежденном суставе. В коллагеновом матриксе (в модели подкожной имплантации) ДНК человека была обнаружена на 5, но не детектировалась на 12 сутки. Выводы. По результатам ПЦР МСК-ВС выживали у животных с остеоартритом в течение короткого периода. Коллагеновый матрикс увеличивал продолжительность пребывания МСК-ВС у реципиентов. МСК-ВС могут рассматриваться как перспективный источник клеток для лечения остеоартрита у человека.

К л юч е в ы е с л о в а: МСК-ВC, альфа-сателлитная ДНК, 3-D матрикс, выживание клеток, ПЦР.

Received 10.02.2015 